Int. J. Dev. Biol. 55: 657-664

doi: $10.1387 /$ ijdb.113340er

\title{
Reproductive Meristem22 is a unique marker for the early stages of stamen development
}

\author{
ELISSON ROMANEL ${ }^{1}$, PRADEEP DAS ${ }^{2}$, RICHARD M. AMASINO ${ }^{3}$, JAN TRAAS $^{2}$, \\ ELLIOT MEYEROWITZ ${ }^{4}$ and MARCIO ALVES-FERREIRA* ${ }^{*}, 1$
}

\begin{abstract}
'Laboratório de Genética Molecular Vegetal (LGMV), Departamento de Genética, Universidade Federal do Rio de Janeiro (UFRJ), Rio de Janeiro, Brazil, ${ }^{2}$ Laboratoire RDP, Ecole Normale Supérieure de Lyon (ENS), Université de Lyon, Lyon, France, ${ }^{3}$ Department of Biochemistry, University of Wisconsin, Madison, WI, USA and

${ }^{4}$ Division of Biology, 156-29, California Institute of Technology, Pasadena, California, USA
\end{abstract}

\begin{abstract}
Stamens undergo a very elaborate development program that gives rise not only to many specific tissue types, but also to the male gametes. The specification of stamen identity is coordinated by a group of homeotic genes such as APETALA3 (AP3) and PISTILLATA (PI), AGAMOUS (AG)and SEPALLATA (SEP1-4) genes. Genome-wide transcriptomic comparisons between floral buds of wild-type and ap3 mutants led to the identification of the REM22 gene, which is expressed in the early stages of stamen development. This gene is member of the plant-specific B3 DNA-binding superfamily. In this work, we dissect the spatio-temporal expression pattern of REM22 during the early stages of stamen development. To this end, both in situ hybridization analyses as well as in vivo fluorescence strategies were employed. At stage 4 of flower development, REM22 is expressed exclusively in those undifferentiated cells of the floral meristem that will give rise to the stamen primordia.At stage 5, REM22 expression is restricted to the epidermal and the subepidermal layers of anther primordia. Later, this expression is confined to the middle layer and the differentiating tapetal cells. After stage 10 when all the tissues of the anther have differentiated, REM22 expression is no longer detectable. Furthermore, we examined the pREM22::GUS-GFP marker line in an inducible system where the ectopic AG function is used to promote microsporogenesis. The data support the idea that REM22 expression is a useful marker to study the early stages of stamen development.
\end{abstract}

KEY WORDS: male sporogenesis, B3 domain, reproductive meristem, stamen development, REM22 function

The development of the Arabidopsis flower is divided into 12 stages (Smyth et al., 1990). Medial anther primordia are visible at stage 5 of flower development and this corresponds to stage 1 of stamen development (Sanders et al., 1999). Stamen development is divided into 14 stages and it ends when the stamen falls off in the senescing flower. Cell division and tissue differentiation occur from stages 1 to 7 of stamen development and these processes culminate with the end of meiosis and the formation of tetrads of free microspores within each locule. At stage 1 of stamen development, cell divisions in the epidermal layer 1 (L1), the sub-epidermal L2 and inner L3 layers of the floral meristem result in the formation of stamen primordia. During stage 2, the cells in the L2 layer divide periclinally (perpendicularly to the layer) to give rise to archesporial cells (AC). At stage 3 , the archesporial cells themselves divide periclinally to give rise to the primary parietal $(P P)$ and the primary sporogenous (PS) layers. At stage 4, the PP layer cells divide periclinally to give rise to the inner secondary parietal layer (ISP) and the outer secondary parietal layer (OSP). At stage 5, OSP cells divisions result in the formation of the endothecium, ISP cells divide periclinally to form a middle layer and tapetal cell and, lastly, PS cells divide to form microspore mother cells.

The patterning of floral organ identity is controlled by the combinatorial activities of the floral homeotic genes, as represented in the ABCE model (Coen and Meyerowitz, 1991, Ditta et al., 2004, Goto et al., 2001, Melzer and Theissen, 2009, Melzer et al., 2009,

Abbreviations used in this paper: AG, AGAMOUS; AP3, APETALA3; DEX, dexamethasone; PI, PISTILLATA; REM, reproductive meristem; SEP, SEPALLATA.

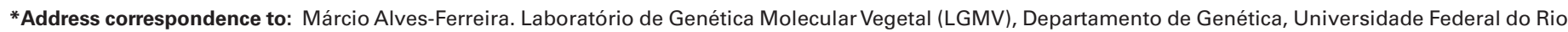

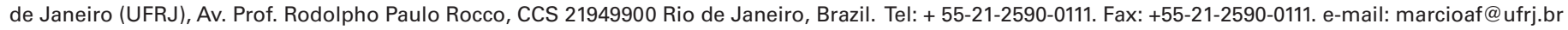

Supplementary Material (a video, two figures and a table) for this paper is available at: http://dx.doi.org/10.1387/ ijdb.113340er
} 
Pelaz et al., 2000). Stamen identity requires the so-called $B, C$ and E functiongenes, APETALA3(AP3), PISTILLATA(PI), AGAMOUS (AG) and SEPALLATA 1-4 (SEP1-4). In the last few years, several genes involved in early stages of stamen development have been identified, such as NZZISPL (NOZZLEISPOROCYTELESS) (Schiefthaler et al., 1999, Yang et al., 1999); EXS/EMS1 (EXTRA SPOROGENOUS CELLSIEXCESSMICROSPOROCYTES1) (Canales et al., 2002); TPD1 (TAPETUM DETERMINANT1) (Yang et al., 2003); SERK1/2(SOMATIC EMBRYOGENESIS1/2) (Albrecht et al., 2005); BAM1/2 (BARELY ANY MERISTEM1/2) (Hord et al., 2006); DYT1 (DYSFUNCTIONAL TAPETUM1) (Zhang etal., 2006); RECEPTOR-LIKE PROTEINS KINASE2 (RPK2) (Mizuno et al., 2007); and $R O X Y 1 / 2$ (Xing and Zachgo, 2008).

Although several mutants with defects at the earliest stages of stamen development have been identified, the molecular events necessary for stamen formation and microspore development are still poorly understood. To fill this gap, several genome-wideanalyses have recently been performed in Arabidopsis thalianato identify the target genes of the ABCE complexes (Alves-Ferreira et al., 2007, Gomez-Mena et al., 2005, Ito et al., 2004, Kaufmann et al., 2009, Wellmer et al., 2006). These studies have revealed the expression of several members of the plant-specific B3 superfamily during the early stages of flower, stamen and carpel development. B3 superfamily genes encompass five families, namely ABI3 ( ABSCISIC ACID INSENSITIVE3) (Suzuki et al., 1997), HSINAL (ㅂigh-level expression of Sugar-Inducible gene/N1/ABB3-like) (Suzuki et al., 2007, Tsukagoshi et al., 2005), ARF (Auxin Response Factor)

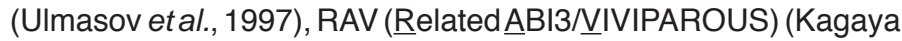
et al., 1999) and REM (Reproductive Meristem) (Franco-Zorrilla et al., 2002). Most of the B3 genes thus identified in reproductive organs belong to the REM family (Romanel et al., 2009). The REM family is composed by 45 members in Arabidopsis, although only two were recently characterized, VERNALIZATION1 (VRN1) and VERDANDI (VDD) (Levy et al., 2002, Matias-Hernandez et al., 2010). In situ expression analyses of several of these REM family genes have shown distinctive spatial expression patterns at specific stages of flower, stamen or carpel development (Alves-Ferreira et al., 2007, Gomez-Mena et al., 2005, Matias-Hernandez et al., 2010, Wellmer et al., 2006, Wijeratne et al., 2007).

REM22 expression was observed at the earlier stages of sta- men and carpel development in previous works (Alves-Ferreira et al., 2007, Gomez-Mena et al., 2005). However the expression pattern was not carefully described and only limited data are available about REM22 tissue specific expression. To test the value of REM22 as a marker of stamen development, we performed a detailed in situ hybridization analysis during stamen development. In parallel, we also fused the promoter region of REM22 to the GUS/GFP reporter genes and evaluated the transgenic lines by in vivo confocal microscopy. This construct was also evaluated in mutants defective in stamen development. Our results provide direct evidence that REM22 expression is a distinctive marker for flower meristem cells undergoing differentiation into stamen primordia. At later stages of flower development, REM22 is expressed strongly and exclusively in the L2-derived cells undergoing differentiation, but not in microspore mother cells and their descendents. This expression pattern is unique and may be valuable to study stamen cell differentiation. The expression of the pREM22::GUS-GFP marker line is very similar to the observed in situ hybridization data, which makes this line a valuable tool for the study of stamen formation and anther development.

\section{Results}

\section{REM22 is expressed during the differentiation of parietal cells in the early stages of stamen development}

To gain a more detailed spatial-temporal understanding of REM22 expression during flower development, we performed a comprehensive in situ hybridization analysis (Fig. 1). REM22 transcripts were detected at stage 3 of flower development in L1 and L2 cell layers (Fig. 1A). At stage 5 of flower development, the transcripts were also detected in the L1 and L2 layers that later generate epidermis and archesporial cells, respectively (Fig. 1B). At stage 6 , high REM22 expression is detected in archesporial cells, but the signal is weak in the epidermis (Fig. 1C). REM22 expression was also detected in parietal cells and in the inner secondary parietal layer. At stage 8 of flower development, REM22 expression is no longer visible in the epidermis and is weakly detected in the outer secondary parietal layer. REM22 is also expressed during carpel development (Fig. 1 D,E,F). At stages 8 and 9 of flower development, a stronger expression was observed in the $L 2$ than in the $L 1$
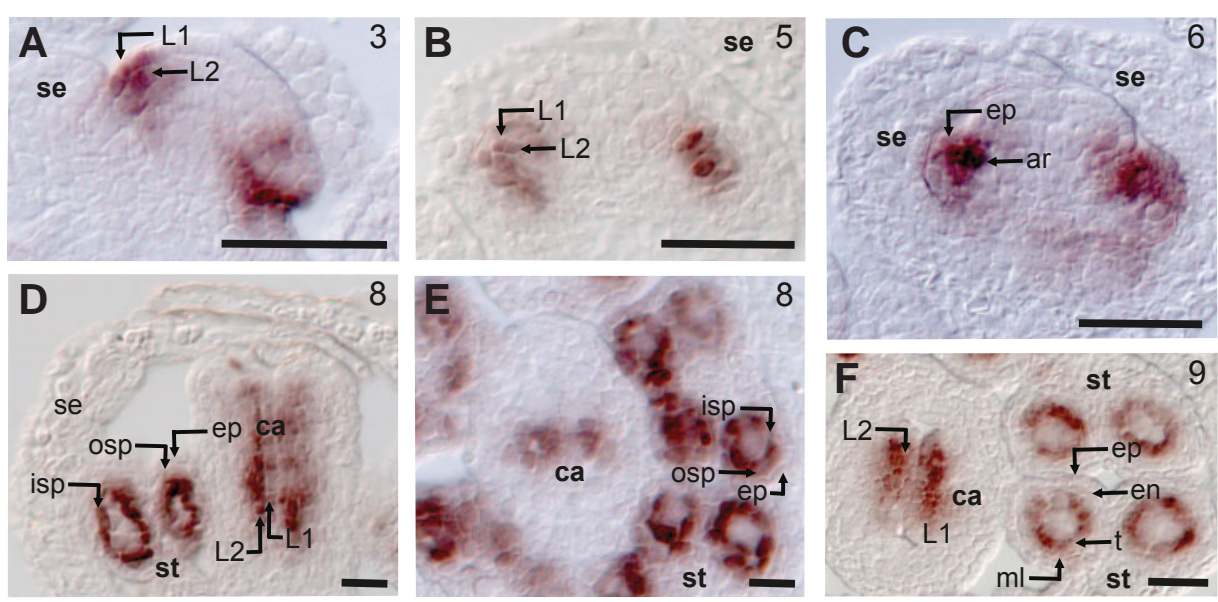

Fig. 1. Expression pattern of REM22 during early stages of wild-type Arabidopsis flower development. (A) Stage 3 flower showing expression of REM22 in L1 and L2 cells. (B) Stage 5 flower showing REM22 expression in $L 1$ and $L 2$ cells. (C) Stage 6 flower showing strong REM22 expression in the archesporial cells and a weaker signal in the epidermis. (D) Stage 8 flower bud longitudinal section, showing higher expression of REM22 in ISP than OSP. REM22 is also expressed in $L 1$ and $L 2$ of the carpel primordia (arrows). (E) Stage 8 flower bud cross section showing REM22 expression in carpels and stamens. (F) Stage 9 flower buds, REM22 shows a high expression in tapetal cells, but it is expressed also in the middle layer cells. Numbers at the upper-right corner of the figures indicate approximate flower stage. $L 1$, layer 1; L2, layer 2; ca, carpel; se, sepal; st, stamen; ar, archesporial cells; ep, epidermis; osp, outer secondary parietal cell; isp, inner secondary parietal cell; en, endothecium; ml; middle layer; $t$ tapetum. Scale bar: $25 \mu \mathrm{m}$. Arrows indicate regions of expression in specific tissues of stamen and carpel. 

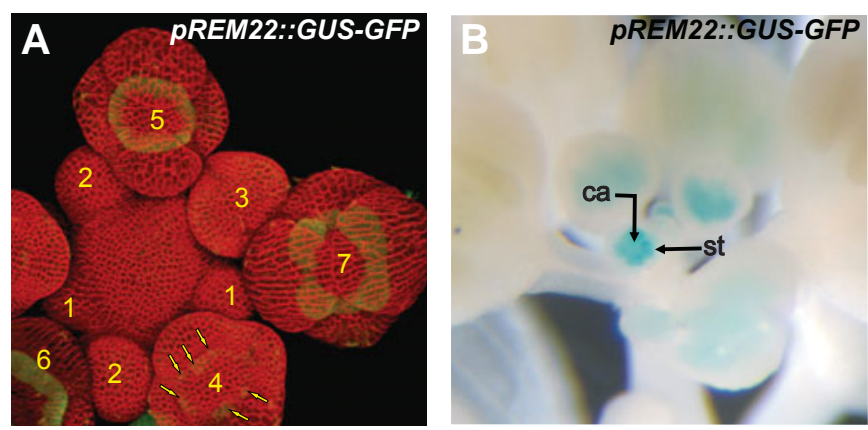

Fig. 2. Confocal microscopy analysis of REM22 promoter activity in wild-type plants. (A) wild-type inflorescence projection ofpREM22::GUSGFP showing weak GFP signal at stage 4 flower bud (arrows) and strong GFP signal at later stages (stage 5 to 7) of flower development. Cell membranes were marked with the dye FM4-64 and GFP fluorescence can be seen as a green signal. (B) wild-type inflorescence of pREM22::GUS-GFP showing GUS staining in stamens (arrows). ca, carpel; st, stamen.

of carpel primordia. The ovule primordia arise in the $\mathrm{L} 2$ layer of carpel primordia in stage 9 of flower development. REM22 expression in male and female reproductive development is similar if we take into consideration tissue differentiation during stamen and carpel development, suggesting that this gene may have a similar function in both processes. At stage 9 of flower development, REM22 hybridization signal was strong in tapetal cells and low in the middle cell layer (Fig. 1 D,E,F). Finally, at late flower development stage 9 , when the stamen tissues are fully differentiated, no signal is observed in any stamen tissue (data not shown).

The expression pattern of REM22 suggests that it may have an important function during Arabidopsis reproductive development. To check this possibility, a T-DNA insertion line for the gene At3g17010 (REM22) was characterized. In the homozygous insertion line for At3g17010 (in which the T-DNAlies in the second exon of the gene), the corresponding complete gene transcripts

Fig. 3. Confocal microscopy of REM22 promoter activity in pREM22::GUS-GFP plants at early stages of stamen development. (B,E,H,I) GFP fluorescence can be seen as a bright green signal. (A,D,GJ) Cell membranes marked with the dye FM4-64, shown in red. $(\mathbf{C}, \mathbf{F}, \mathbf{I}, \mathbf{L})$ Merged confocal images from $A / B, D / E$, $G / H$ and J/K figures. (C) Predominant localization of GFP signal in L1 and L2 cells in the third whorl of a stage 5 flower bud. (F) GFP signal in epidermis and archesporial cells at a stage 6 flower bud. (I) GFP signal in epidermis and primary parietal cell at stage 7 flower bud. (L) stage 9 flower buds shows a strong GFP signal in the tapetum layer and a weak signal in the middle layer. (M) Diagram depicting cell lineages during wild-type anther development. The green boxes enclose cell types were the expression of REM22 is observed. The bar below the diagram shows stages of flower and anther development described by Smyth et al., (1991) and Sanders et al., (1999), respectively (adapted from Alves-Ferreira et al.; 2007). Numbers at the upper-right corner of the figures indicate approximate flower stage. L1, layer 1; L2, layer 2; ca, carpel; se, sepal; st, stamen; ar, archesporial cells; ep, epidermis; pp, primary parietal cell; sp, sporogenous primary; en, endothecium; $\mathrm{ml}$; middle layer; t, tapetum; m, microspore. Scale bar: approximately $50 \mu \mathrm{m}$. were not detectable (Supplementary Fig. 1). The T-DNA insertion line had no discernable mutant phenotype (data not shown).

\section{REM22 reporter lines display expression similar to in situ hybridization expression patterns}

In order to obtain a marker line for the REM22 expression pattern, we cloned a fragment with $1022 \mathrm{bp}$ upstream of the ATG start codon. This DNA fragment corresponds to the entire genomic region between At3g17010 and the upstream gene At3g17000 (Supplementary Fig. 2). The fragment was fused to the reporter genes GUS/GFP in the vector pKGWFS7 by recombination and the resultant construct, named pREM22::GUS-GFP, was transformed into Arabidopsis thaliana wild-type plants using the floral dipping method (Clough and Bent, 1998). Five out of fifteen primary trans-
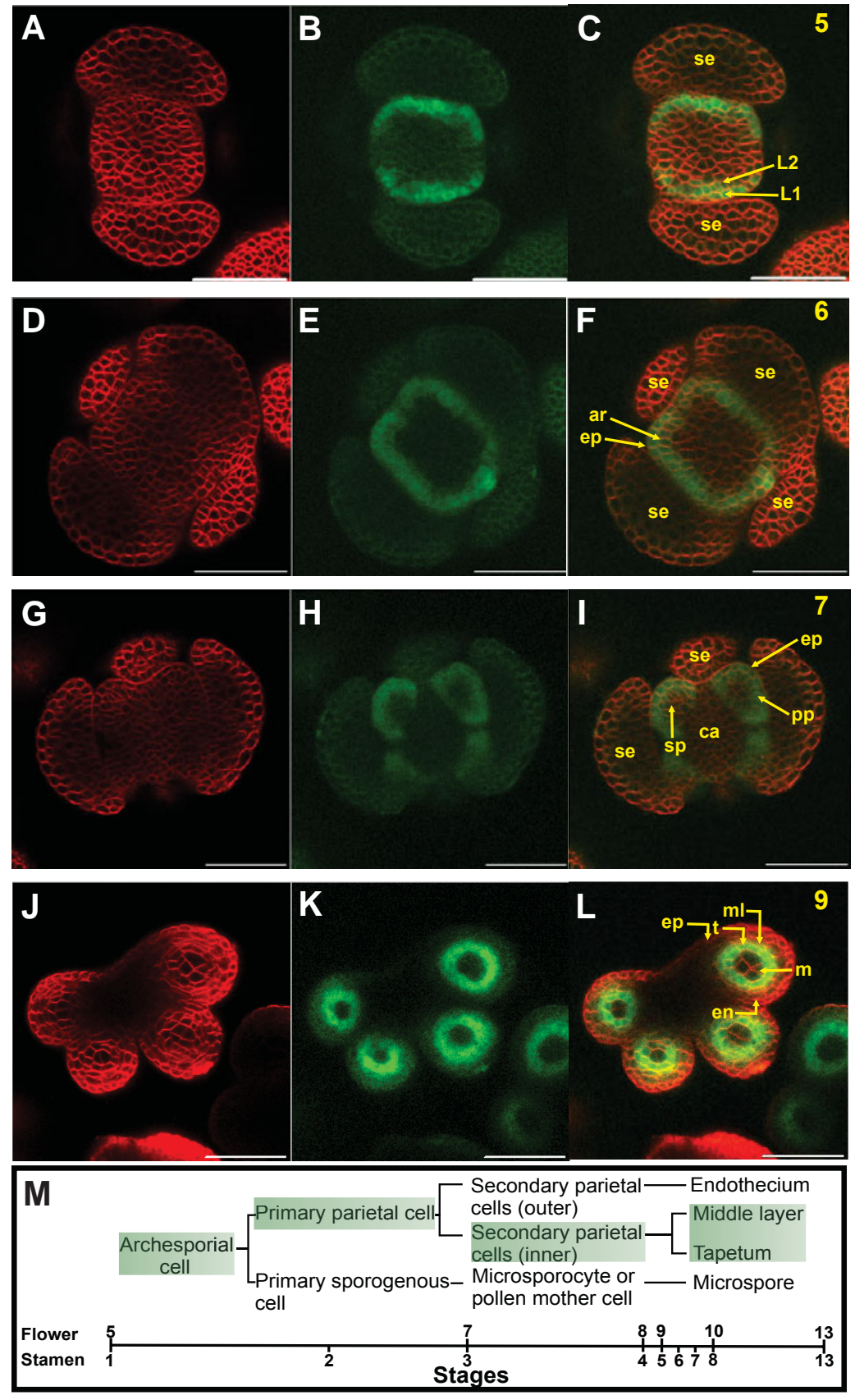

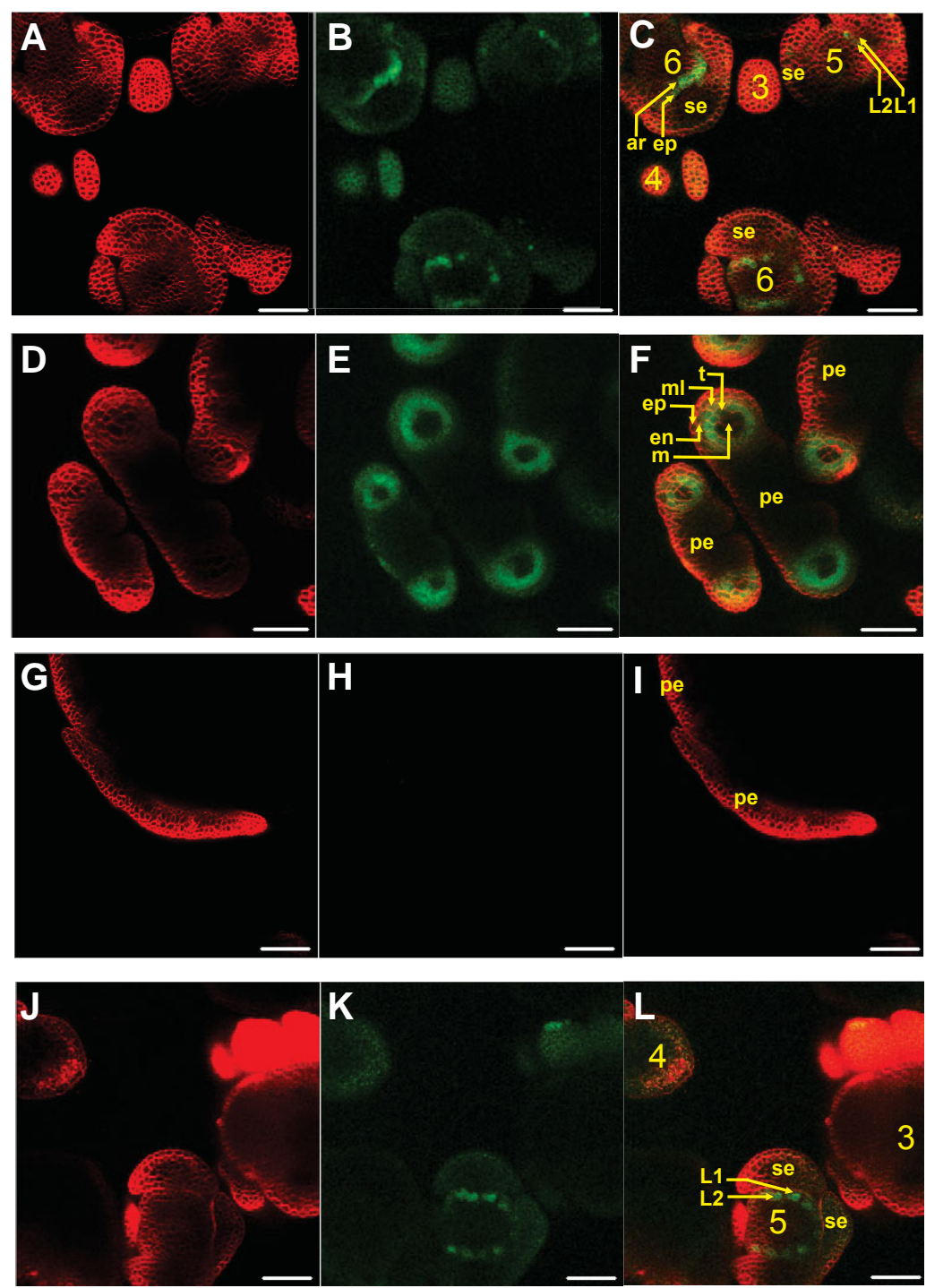

Fig. 4. Confocal microscopy of pREM22::GUS-GFPpromoter activity in p35S::AG$\mathbf{G R}$, ag background. GFP fluorescence can be seen as a bright green signal in (B,E,K) $(\mathbf{A}, \mathbf{D}, \mathbf{G}, \mathbf{J})$ Cell membranes marked with the dye FM4-64 are shown in red. $(\mathbf{C}, \mathbf{F}, \mathbf{I}, \mathbf{L})$ Merged confocal images of $A / B, D / E, G / H$ and J/K. (C) Inflorescence of $35 S:: A G-G R$, ag/ pREM22::GUS-GFP line under continuous DEX treatment showing GFP signal at stage 5 and 6 flower bud. (F) p35S::AG-GR, ag treated with DEX at a late stage of flower development showing GFP signal in staminoid petals in different stages of development. (I) p35S::AG-GR, ag/ pREM22::GUS-GFP not treated with DEX at late stage showing no change in petals and no GFP expression. (L) Inflorescence of 35 S::AG-GR, ag/ pREM22::GUS-GFP showing GFP signal at stages 5 flower bud without the presence of functional $A G$ protein. Numbers in $(\mathbf{C}, \mathbf{L})$ indicate the flower stage. L1, layer 1; L2, layer 2; se, sepal; pe, petal; ep, epidermis; en, endothecium; $\mathrm{ml}$, middle layer; $t$, tapetum; $m$, microspore. Scale bar: $50 \mu \mathrm{m}$.

formants (\#17.02; \#17.08; \#17.11; \#17.13 and \#17.15) showed a segregation of 3:1 for antibiotic resistance, indicating the presence of only one T-DNA locus in these lines. Homozygous transformant lines were obtained and the GUS expression was evaluated in reproductive tissues during development. Three out of the four homozygous lines (\#17.02; \#17.08 and \#17.13) showed GUS staining during anther and ovule development (Fig. 2B) similar to the expression pattern observed previously by in situ.
To better investigate the spatial and temporal expression pattern of REM22, we used confocal-based live imaging in the line $p R E M 22:: G U S-G F P / \# 17.13$ during the early stages of flower development. GFP expression was observed at stages 4 to 9 of flower development (Figs. 2A and 3). While only a very low expression is detected in $\mathrm{L} 1$ and $\mathrm{L} 2$ cells during stage 4 of flower buds in the line \#17.13 (Fig. $2 \mathrm{~A}$, Supplementary Video 1), our in situ results clearly show that REM22 expression in $\mathrm{L} 1$ and $\mathrm{L} 2$ cells begins at stage 3 (Fig. 1A). The absence of GFP signal at stage 3 of flower development and weak GFP signal at stage 4 could be explained by the sensitivity of techniques and/or absence of some cis elements in the promoter fragment we used in the construct.

At stage 5 of flower development, when the petals and stamen whorls are well defined, the GFP signal is observed exclusively in L1 and L2 cells of the third whorl, in agreement with the in situ hybridization analysis (Fig. 3 A-C). At stage 6 of flower development, GFP expression appears to become restricted to the $\mathrm{L} 1$ and $\mathrm{L} 2$ cells that have begun to differentiate into archesporial cells (Fig. 3 D-F). This expression pattern is similar to REM22 transcripts, though the in situ hybridization data showed a stronger hybridization signal in the archesporial cells when compared to the epidermis. At stage 7 of flower development, GFP expression continues in the epidermis and primary parietal layer (Fig. $3 \mathrm{G}-\mathrm{I}$ ). We also can observe GFP expression in cells of the inner secondary parietal layer. At this stage, however, no REM22 RNA is detected in the epidermis. One explanation for these minor discrepancies could be that the GFP-GUS chimeric protein is more stable than REM22 transcripts, and it persists through cell divisions.

At the stage 9 of flower development, when all tissues of mature stamens are present, GFP signal is observed exclusively in tapetal cells and in the middle cell layer (Fig. $3 \mathrm{~J}-\mathrm{L}$ ). These data overlap perfectly with REM22 in situ hybridization data at stages 8 and 9. REM22 expression is weaker in the outer secondary parietal cells than in the inner secondary parietal cells (ISPC), which differentiate into the middle cell layer and tapetal cells (Fig. 3M). The expression of REM22 observed by in situ as well as in vivo experiments showed that REM22 is expressed at high level in ISPC until early stage 10 of flower development, when these tissues are not totally differentiated.

\section{Spatial and temporal expression patterns of pREM22::GUS-GFP in the inducible AGAMOUS func- tion system}

To determine how useful the pREM22::GUS-GFP reporter line could be in studying stamen development, we crossed the line with $p 35 S:: A G-G R$, ag background that is an excellent tool to examine male reproductive development.

We exploited an inducible system where an ectopic AG function is used to promote microsporogenesis. This p35S::AG-GR, ag line constitutively expresses an inducible version of $A G$ fused to the rat glucocorticoid domain GR (Ito et al., 2004). The chimeric AG-GR protein is inactive in the cytoplasm, but after exposure to the synthetic glucocorticoid dexamethasone (DEX), it translocates to the nucleus where it can activate the expression of $A G$ target 
genes. The induction of AG function in this line results in flowers with functional stamens and carpels, which resemble the flowers of 35S::AG plants (Ito et al., 2004).

After DEX treatment, $p 35 S:: A G-G R$, ag plants carrying the pREM22::GUS-GFPconstruct display the development of wild-type stamen structures, as previously shown (Gomez-Mena et al., 2005, Ito et al., 2007, Ito et al., 2004). Confocal-based live imaging of these plants at stage 6 of flower development showed that GFP expression is very similar to that observed in pREM22::GUS-GFP plants (Fig. 4 A-C), though the GFP signal is weaker and more diffuse. The induction of these plants with DEX activates NZZ/SPL exclusively in lateral edges of the distal parts of organ primordial giving rise to a petal with one locule on each either side (Ito et al., 2004). In agreement with this, at later stages of development, GFP expression is observed in the middle cell layer and tapetal cells of all staminoid petals (Fig. 4 D-F). Therefore, these results indicate that stamen differentiation proceeds normally in $p 35 S:: A G$ GR, ag plants and furthermore, that the line pREM22::GUS-GFP is a valuable marker for tracing stamen histodifferentiation. In pREM22::GUS-GFP, ag plants, we observed low levels of GFP expression in L1 and L2 cells (Fig. $4 \mathrm{~J}-\mathrm{L}$ ) at stage 5 of flower development. This data suggests that early expression of REM22 is independent of $A G$ function.

\section{Discussion}

The present work provides a detailed analysis of REM22 mRNA expression. The in situ hybridization analysis and the confocalbased live imaging study of pREM22::GUS-GFP plants revealed that the fragment of 1022 bp contains the majority of the control elements necessary to stamen expression. The unique expression pattern of REM22 during early stamen development makes it a potential candidate for a stamen marker. In order to demonstrate the usefulness of the pREM22::GUS-GFP plants we crossed it to the line $p 35 S:: A G-G R$, ag. The results support the concept that this line can be useful to identify the anther primordial position. The promoter activity of REM22 is also observed in L1 and L2 of carpel primordia only at stage 8 , when the key events of stamen differentiation such as stamen identity, archeosporial initiation and parietal and microspore precursor formation have already taken place. After stage 10, REM22 expression is observed during ovule development when its expression is off in stamens. Although, the REM22 promoter activity in carpels may hinder its usefulness at later flower stages, its high specific expression at early stages of stamen development can be very useful for characterization of novel mutant backgrounds with stamen identity problems or with defects in stamen differentiation at early stages. Our data also suggests that early expression of REM22 is independent of AG function. Based on electrophoretic mobility shift assays (EMSA), it has been proposed that the AG protein binds to a putative CArG box located at position -1570 bp of the REM22 promoter (GomezMena et al., 2005). However, since our pREM22::GUS-GFP only contains sequences from -1 to -1022 bp and does not contain the putative CArG box, it is likely that the work described here does not evaluate the influence of this putative cis element on the REM22 expression pattern. Equally, it is possible that the EMSA results are artifactual, since it is not an in vivo assay.

The lack of a mutant phenotype in the REM 22 knock out line is likely a consequence of the high degree of functional redundancy found in Arabidopsis, especially among member of REM family (Romanel et al., 2009). In fact, there are two REM22 close homologues in the Arabidopsis genome, REM 20 and REM 21 (Romanel et al., 2009). REM20, named VERDANDI, was recently identified and the characterization of female gametophytes in the T-DNA insertion line indicates that antipodal and synergid cell identity and/or differentiation are affected (Matias-Hernandez et al., 2010).

REM22 expression, when compared to other marker genes already characterized during reproductive development, is unique. It has an expression restricted to few cells, the precursors of stamen primordia, in the floral meristem when APETALA1 (AP1)

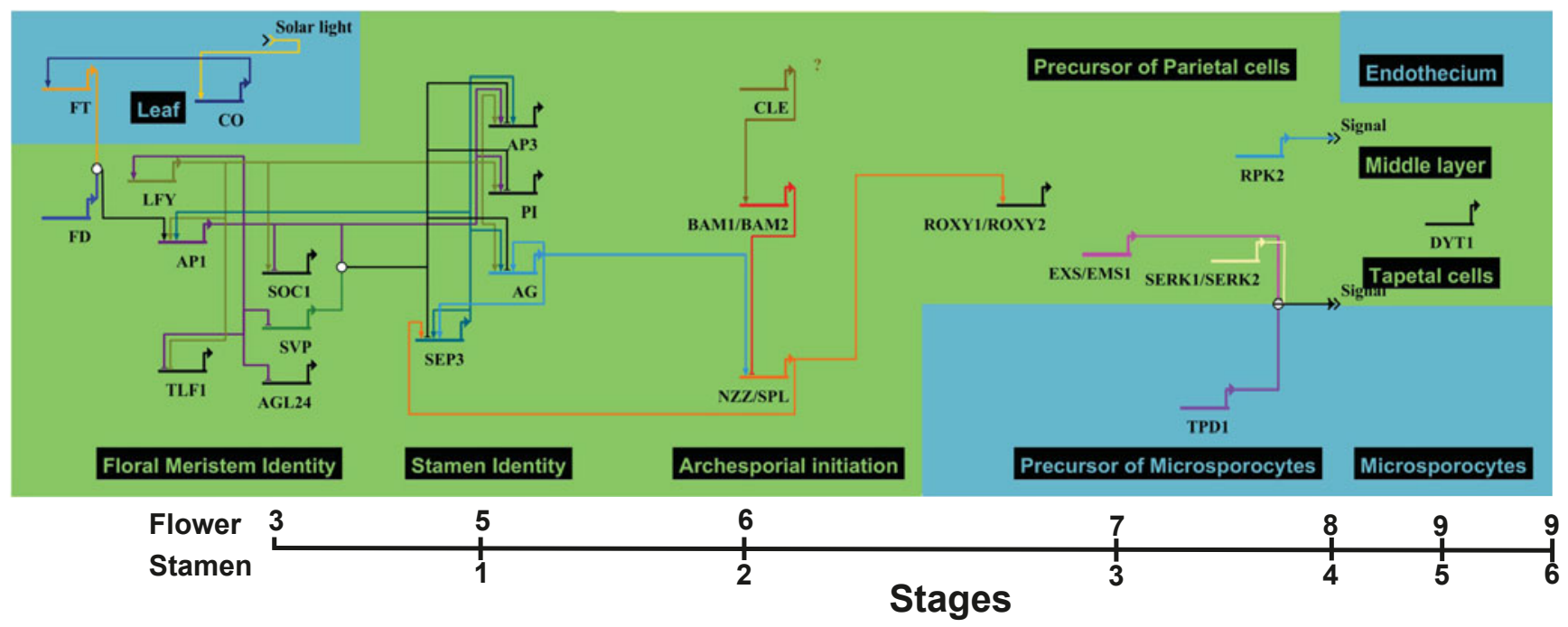

Fig. 5. Gene regulatory network controlling early stages of stamen development in Arabidopsis thaliana. Genes that respond to circadian clock genes, floral-promotion genes, floral meristem identity genes, stamen identity genes and genes necessary for stamen tissue differentiation are shown. Individual genes are represented by horizontal lines with bent arrows and gene symbols. For each gene, upstream inputs and downstream targets are indicated. Activators are connected to their target by arrow, repressors by blunted lines. White circles represent protein interactions. Arrows with "signal" symbolize that gene or protein interactions are responsible for triggering the development of the next step. The green area represents the expression domain of the REM22 marker gene. Diagram was generated using BioTapestry (Longabaugh et al., 2005) and is based on published data (see text) 
and $L E A F Y$ ( $L F Y$ ) RNAs accumulate uniformly throughout young floral primordia (Bowman et al., 1993, Mandel et al., 1992, Weigel et al., 1992). Later, at stage 5, when the expression of ABCE genes is observed, REM22 is expressed exclusively in the L1 and L2 of only in the third whord. AP3 transcripts accumulate in the precursors of stamen, but also precursors of petals prior to the differentiation of these organs (Jack et al., 1992). During stamen tissue differentiation, REM22 expression is restricted to archesporial cells where is also expressed BAM1/BAM2 and NZZ (Hord et al., 2006, Schiefthaler et al., 1999). At stage 7, ROXY1/ROXY2 (Xing and Zachgo, 2008), BAM1/BAM2 and EXS/EMS1 RNA is limited to the primary parietal and primary sporogenous cells near the lateral edges of anthers whereas $N Z Z$ is broadly expressed in stamen tissues. From stages 3 to 8, REM22 RNA expression is distinctive when compared with ROXY1/ROXY2, EXS1/EMS1, $S E R K 1 / S E R K 2$ and $R P K 2$, been restricted to primary parietal cells and inner secondary parietal cells at stage 8 (Fig. 5) (Canales et al., 2002, Colcombet et al., 2005, Xing and Zachgo, 2008, Zhao et al., 2002). Finally, with the differentiation of the endothecium, middle layer, tapetal cells and microspores, REM22 expression is similar to SERK1/SERK2 (Colcombet et al., 2005), restricted to the middle layer and tapetum tissue.

The REM22 promoter can also be a useful tool for genome wide tissue/cell specific expression studies, or translatome analysis, as well as chromatin immunoprecipitation assays for those interested in mechanisms of transcriptional regulation during early tissue differentiation in stamens. Moreover, its association with the floral induction system in Arabidopsis developed by Wellmer and collaborators that allows the isolation of a large number of synchronized floral buds in a specific floral stage, could make it more sensitive by enriching the biological sample with particular tissue types of a specific developmental stage (Wellmer et al., 2006).

\section{Materials and Methods}

\section{Plant material, growth conditions}

The Arabidopsis Thaliana Landsberg Erecta (Ler) was used as wildtype control for plants transformed with constructed vector. The $A$. thaliana Columbia (Col) was used as wild-type control for plants carrying T-DNA insertion. The rem22-2 (SALK_091149) insertion line was isolated from Salk collection (http://signal.salk.edu) (Alonso et al., 2003). The T-DNA line used in this work is in Col background. Seeds were stored at $4^{\circ} \mathrm{C}$ for all the time. To conduct the experiments, seeds from Salk collection were surface rinsed and sterilized with ethanol $100 \%$ for 5 minutes, and then germinated in soil under short ( $16 \mathrm{Hs}$ dark/8Hs light) and long-day conditions (16Hs light/8Hs dark) at 19 to $23^{\circ} \mathrm{C}$. Seeds containing constructed plasmid were surface sterilized with ethanol $70 \%$ for 5 minutes, rinsed with ethanol $100 \%$, and then germinated and grown on Murashige and Skoog medium (Murashige and Skoog, 1962) under long-day conditions at 19 to $23^{\circ} \mathrm{C}$. After two weeks, seedlings were transferred to a mix of vermiculite and soil at the same conditions for growth.

\section{Genotyping and gene expression analysis}

Segregation analysis and genotyping were applied to isolate lines homozygous for a T-DNA insertion. Primers LP (5'-TTGAAAAGTTAGATCTTTCAGCTTTG-3') and RP (5'-TATGGTTTGAATCTTACCAGGAACT-3') were used to amplify a wild-type or an insertion allele of a gene in combination with the T-DNA-specific primer LBb1 (5\#- CAAACCAGCGTGGACCGCTTGCTG -3'). The exact positions of T-DNA insertion in the lineSALK_091149 (target gene At3g17010) was determined by sequencing of the resulting PCR products. Total RNA was isolated with the RNeasy
RNA isolation kit followed by DNase I treatment (Qiagen) from $100 \mathrm{mg}$ of whole inflorescences of REM22 knock out line and wild-type plants, respectively. cDNA was generated from two independent RNA preparations for each genotype using MLV-RT First-Strand Synthesis System (Promega) according to the manufacturer's instructions. Primers used for RT-PCR (Supplementary Table 1) were designed to amplify 400- to 450-bp (RT-PCR) long fragments of CDNA. UBQ10 (AT4G05320) was used to normalize the mRNA sources (Michaels et al., 2004). For PCR, reactions were carried out in a total volume of $25 \mu \mathrm{L}$ with $0.4 \mathrm{mM}$ primers and $200 \mathrm{mM}$ dNTPs using Ex-Taq polymerase (Takara) according to the manufacturer's instructions. PCR conditions were as follows: $94^{\circ} \mathrm{C}$ for $4 \mathrm{~min} ; 20$ to 35 cycles of $94^{\circ} \mathrm{C}$ for $30 \mathrm{~s}, 55^{\circ} \mathrm{C}$ for $1 \mathrm{~min}, 72^{\circ} \mathrm{C}$ for $1 \mathrm{~min}$; followed by an elongation step at $72^{\circ} \mathrm{C}$ for $10 \mathrm{~min}$. The amplification products were visualized on a $1 \%(\mathrm{w} / \mathrm{v})$ agarose gel via ethidium bromide staining.

\section{Plasmid construct and generation of transgenic plants}

To obtain the complete promoter region from At3g17010 (REM22), the 1022 bp upstream ATG was cloned into a binary vector pKGWFS7 (GUS/ GFP) using the Gateway cloning technology and sequenced to confirm the fidelity of the promoter sequences. The pREM22::GUS-GFP construct was introduced into the Agrobacterium tumefaciens strain GV3101 and transformed into Arabidopsis Thalianawild-type Ler by the floral dip method (Clough and Bent, 1998). T2 lines segregating for kanamycin resistance (25 $\mu \mathrm{g} / \mathrm{mL}$ ) with an approximately 3:1 ratio were selected for further analysis.

\section{DEX treatment and pREM22::GUS-GFP in ag 35S:AG-GR background}

Plants carrying p35S::AG-GR, ag background (Ito et al., 2004) were treated every day for one week by submerging the inflorescences in a solution containing $10 \mathrm{uM}$ DEX together with $0.015 \%$ Silwet L-77 for $\sim 1$ min. One recovered transgenic $p 35 S:: A G-G R$, ag line was crossed with pREM22::GUS-GFP plants to obtain lines in subsequent generations. F2 generation inflorescences of ag-135S::AG-GR/pREM22::GUS-GFPplants with agamous phenotypes were chosen to genotype with GUS primer 5' - GCGACGCTCACACCGATAC - 3' and 5' - ACTGCTTTTTCTTGCCGTTTTC - 3' and GR primer 5' - ATGGCTAGTGAAGCTCGAAAAACA - 3' and 5' - TTTTTGATGAAACAGAAGCTT- 3'. Plants positive for both primers were used in the experiment. Some control plants were mocktreated and some plants were continuously treated with DEX for 5 days once a day. These plants were observed by live imaging.

\section{Tissue preparation for live imaging}

The presence of the GFP protein was determined in primary inflorescence containing floral buds of stage 1-12 living tissue. They were prepared by cutting off flowers older than stage 13. These inflorescences were transferred into clear plastic boxes containing MS-agar. We applied $10 \mu \mathrm{g}$ ml-1 FM4-64 (Molecular Probes), a water-soluble lipophilic dye, directly onto the inflorescence meristem $\mathbf{3 0} \mathrm{min}$ prior to imaging. Confocal laser scanning microscopy of the living plant tissue was performed with Zeiss 510L SM Meta with water dipping 63x objective achroplan lens. Stacks of 30 sections spaced approximately $1.5 \mu \mathrm{m}$ apart were collected every $2 \mathrm{hr}$. Visualization of sections and volume was performed using the Zeiss LSM software.

\section{Histochemical GUS Staining and histological analysis}

Inflorescence plants were collected and placed in $90 \%$ ice-cold acetone for $30 \mathrm{~min}$, washed in staining $0.1 \mathrm{M}$ phosphate buffer, $\mathrm{pH} 7.0$, and incubated overnight at $37^{\circ} \mathrm{C}$ in buffer with $2 \mathrm{mM} \mathrm{X}$-Gluc substrate, $1 \mathrm{mM}$ potassium ferricyanide, and $1 \mathrm{mM}$ potassium ferrocyanide. The plant material was stored in $70 \%$ ethanol until analyzed.

\section{Probe making and in situ hybridization}

Constructs used for probes generation and oligonucleotide sequences are described earlier (Alves-Ferreira et al., 2007). All the steps of in situ hybridization were carried out according to the protocol described by AlvesFerreira and collaborators (2007). 


\section{Accession numbers}

Arabidopsis Genome Initiative locus identifiers of Arabidopsis genes used in this article are as follow: AG (At4g17010), UBQ (At4g05320) and REM22 (At3g17010).

\section{Acknowledgements}

E.R. thanks Annick Dubois and Pradeep Das for friendship and hosting assistance to develop this work; to Robert Franks for comments on the manuscript; and to Marcus Heisler for initial analysis of REM22 marker line by confocal microscopy. M.A.-F. was supported by grants from CNPq and Fundação de Amparo à Pesquisa do Rio de Janeiro (FAPERJ; M. Alves-Ferreira: \#E-26/102.861/2008). This work is part of E.R. 'PhD thesis from Department of Genetics of the Universidade Federal do Rio de Janeiro, Brazil. E.R. was supported by a PhD studentship (Conselho Nacional de Desenvolvimento Científico e Tecnológico (CNPq) and UNESCO.

\section{References}

ALBRECHT, C., RUSSINOVA, E., HECHT, V., BAAIJENS, E. and DE VRIES, S. (2005). The Arabidopsis Thaliana SOMATIC EMBRYOGENESIS RECEPTORLIKE KINASES1 and 2 control male sporogenesis. Plant Cell 17: 3337-3349.

ALVES-FERREIRA, M., WELLMER, F., BANHARA, A., KUMAR, V., RIECHMANN, J.L. and MEYEROWITZ, E.M. (2007). Global expression profiling applied to the analysis of Arabidopsis stamen development. Plant Physiol. 145: 747-762.

BOWMAN, J.L., ALVAREZ, J., WEIGEL, D., MEYEROWITZ, E.M. and SMYTH, D.R. (1993). CONTROLOF FLOWERDEVELOPMENT IN ARABIDOPSIS-THALIANA BY APETALA1 AND INTERACTING GENES. Development 119: 721-743.

CANALES, C., BHATT, A.M., SCOTT, R. and DICKINSON, H. (2002). EXS, a putative LRR receptor kinase, regulates male germline cell number and tapetal identity and promotes seed development in Arabidopsis. Curr. Biol. 12: 1718-1727.

CLOUGH, S.J. and BENT, A.F. (1998). Floral dip: a simplified method for Agrobacterium-mediated transformation of Arabidopsis Thaliana. Plant J. 16: 735-743.

COEN, E.S. and MEYEROWITZ, E.M. (1991). The War of the Whorls - Genetic Interactions Controlling Flower Development. Nature 353: 31-37.

COLCOMBET, J., BOISSON-DERNIER, A., ROS-PALAU, R., VERA, C.E. and SCHROEDER, J.I. (2005). Arabidopsis SOMATIC EMBRYOGENESIS RECEPTOR KINASES1 and 2 are essential for tapetum development and microspore maturation. Plant Cell 17: 3350-3361.

DITTA, G., PINYOPICH, A., ROBLES, P., PELAZ, S. and YANOFSKY, M.F. (2004). The SEP4 gene of Arabidopsis Thaliana functions in floral organ and meristem identity. Curr. Biol. 14: 1935-1940.

FRANCO-ZORRILLA, J.M., CUBAS, P., JARILLO, J.A., FERNANDEZ-CALVIN, B. SALINAS, J. and MARTINEZ-ZAPATER, J.M. (2002). AtREM1, a member of a new family of $B 3$ domain-containing genes, is preferentially expressed in reproductive meristems. Plant Physiol. 128: 418-427.

GOMEZ-MENA, C., DE FOLTER, S., COSTA, M.M.R., ANGENENT, G.C. and SABLOWSKI, R. (2005). Transcriptional program controlled by the floral homeotic gene AGAMOUS during early organogenesis. Development 132: 429-438.

GOTO, K., KYOZUKA, J. and BOWMAN, J.L. (2001). Turning floral organs into leaves, leaves into floral organs. Curr. Opin. Genet. Dev. 11: 449-456.

HORD, C.L.H., CHEN, C.B., DEYOUNG, B.J., CLARK, S.E. and MA, H. (2006). The BAM1/BAM2 receptor-like kinases are important regulators of Arabidopsis early anther development. Plant Cell 18: 1667-1680.

ITO, T., NG, K.H., LIM, T.S., YU, H. and MEYEROWITZ, E.M. (2007). The homeotic protein AGAMOUS controls late stamen development by regulating a jasmonate biosynthetic gene in Arabidopsis. Plant Cell 19: 3516-3529.

ITO, T., WELLMER, F., YU, H., DAS, P., ITO, N., ALVES-FERREIRA, M., RIECHMANN, J.L. and MEYEROWITZ, E.M. (2004). The homeotic protein AGAMOUS controls microsporogenesis by regulation of SPOROCYTELESS. Nature 430: 356-360.

JACK, T., BROCKMAN, L.L. and MEYEROWITZ, E.M. (1992). THE HOMEOTIC GENEAPETALA3 OF ARABIDOPSIS-THALIANA ENCODES AMADS BOXAND IS EXPRESSED IN PETALS AND STAMENS. Cell 68: 683-697.

KAGAYA, Y., OHMIYA, K. and HATTORI, T. (1999). RAV1, a novel DNA-binding protein, binds to bipartite recognition sequence through two distinct DNA-binding domains uniquely found in higher plants. Nucl. Acids Res. 27: 470-478.
KAUFMANN, K., MUINO, J.M., JAUREGUI, R., AIROLDI, C.A., SMACZNIAK, C., KRAJEWSKI, P. and ANGENENT, G.C. (2009). Target Genes of the MADS Transcription Factor SEPALLATA3: Integration of Developmental and Hormonal Pathways in the Arabidopsis Flower. PLoS Biology 7: 854-875.

LEVY, Y.Y., MESNAGE, S., MYLNE, J.S., GENDALL, A.R. and DEAN, C. (2002). Multiple roles of Arabidopsis VRN1 in vernalization and flowering time control. Science 297: 243-246.

LONGABAUGH, W.J.R., DAVIDSON, E.H. and BOLOURI, H. (2005). Computational representation of developmental genetic regulatory networks. Dev. Biol. 283:1-16.

MANDEL, M.A., GUSTAFSONBROWN, C., SAVIDGE, B. and YANOFSKY, M.F. (1992). MOLECULAR CHARACTERIZATION OF THE ARABIDOPSIS FLORAL HOMEOTIC GENE APETALA1. Nature 360: 273-277.

MATIAS-HERNANDEZ, L., BATTAGLIA, R., GALBIATI, F., RUBES, M., EICHENBERGER, C., GROSSNIKLAUS, U., KATER, M.M. and COLOMBO, L. (2010). VERDANDI Is a Direct Target of the MADS Domain Ovule Identity Complex and Affects Embryo Sac Differentiation in Arabidopsis. Plant Cell 22: 1702-1715.

MELZER, R. and THEISSEN, G. (2009). Reconstitution of floral quartets in vitroinvolving class B and class E floral homeotic proteins. Nucleic Acids Res. 37: 2723-2736.

MELZER, R., VERELST, W. and THEISSEN, G. (2009). The class E floral homeotic protein SEPALLATA3 is sufficient to loop DNA in floral quartet-like complexes in vitro. Nucleic Acids Res. 37: 144-157.

MIZUNO, S., OSAKABE, Y., MARUYAMA, K., ITO, T., SATO, T., SHINOZAKI, K. and YAMAGUCHI-SHINOZAKI, K. (2007). RPK2 is a novel factor controlling anther development in Arabidopsis Thaliana. Plant Cell Physiol. 48: S229-S229.

MURASHIGE, T. and SKOOG, F. (1962). A revised medium for rapid growth and bio assays with tobacco tissue cultures. Physiologia Plantarum 15: 473-497.

PELAZ, S., DITTA, G.S., BAUMANN, E., WISMAN, E. and YANOFSKY, M.F. (2000) $B$ and $C$ floral organ identity functions require SEPALLATA MADS-box genes. Nature 405: 200-203.

ROMANEL, E.A.C., SCHRAGO, C.G., COUÃ $\pm A G O, R . M ., R U S S O$, C.A.M. and ALVES-FERREIRA, M.R. (2009). Evolution of the B3 DNA Binding Superfamily: New Insights into REM Family Gene Diversification. PLOS ONE 4: e5791.

SANDERS, P.M., BUI, A.Q., WETERINGS, K., MCINTIRE, K.N., HSU, Y.C., LEE, P.Y., TRUONG, M.T., BEALS, T.P. and GOLDBERG, R.B. (1999). Anther developmental defects in Arabidopsis Thaliana male-sterile mutants. Sexual Plant Reprod. 11: 297-322.

SCHIEFTHALER, U., BALASUBRAMANIAN, S., SIEBER, P., CHEVAliER, D., WISMAN, E. and SCHNEITZ, K. (1999). Molecular analysis of NOZZLE, a gene involved in pattern formation and early sporogenesis during sex organ development in Arabidopsis Thaliana. Proc. Natl. Acad. Sci. USA 96: 11664-11669.

SMYTH, D.R., BOWMAN, J.L. and MEYEROWITZ, E.M. (1990). Early Flower Development in Arabidopsis. Plant Cell 2: 755-767.

SUZUKI, M., KAO, C.Y. and MCCARTY, D.R. (1997). The Conserved B3 Domain of VIVIPAROUS1 Has a Cooperative DNA Binding Activity. Plant Cell 9: 799-807.

SUZUKI, M., WANG, H.H.Y. and MCCARTY, D.R. (2007). Repression of the LEAFY COTYLEDON 1/B3 Regulatory Network in Plant Embryo Development by VP1/ ABSCISIC ACID INSENSITIVE 3-LIKE B3 Genes. Plant Physiol. 143: 902-911.

TSUKAGOSHI, H., SAIJO, T., SHIBATA, D., MORIKAMI, A. and NAKAMURA, K. (2005). Analysis of a sugar response mutant of Arabidopsis identified a novel B3 domain protein that functions as an active transcriptional repressor. Plant Physiol. 138: 675-685.

ULMASOV, T., HAGEN, G. and GUILFOYLE, T.J. (1997). ARF1, a transcription factor that binds to auxin response elements. Science 276: 1865-1868.

WEIGEL, D., ALVAREZ, J., SMYTH, D.R., YANOFSKY, M.F. and MEYEROWITZ, E.M (1992). LEAFY CONTROLS FLORAL MERISTEM IDENTITY IN ARABIDOPSIS. Cell 69: 843-859.

WELLMER, F., ALVES-FERREIRA, M., DUBOIS, A., RIECHMANN, J.L. and MEYEROWITZ, E.M. (2006). Genome-wide analysis of gene expression during early Arabidopsis flower development. Plos Genetics 2: 1012-1024.

WIJERATNE, A.J., ZHANG, W., SUN, Y.J., LIU, W.L., ALBERT, R., ZHENG, Z.Q., OPPENHEIMER, D.G., ZHAO, D.Z. and MA, H. (2007). Differential gene expression in Arabidopsis wild-type and mutant anthers: insights into anther cell differentiation and regulatory networks. Plant J. 52: 14-29.

XING, S. and ZACHGO, S. (2008). ROXY1 and ROXY2, two Arabidopsisglutaredoxin genes, are required for anther development. Plant J. 53: 790-801. 
YANG, S.L., XIEA, L.F., MAO, H.Z., PUAH, C.S., YANG, W.C., JIANG, L.X., SUNDARESAN, V. and YE, D. (2003). TAPETUM DETERMINANT1 is required for cell specialization in the Arabidopsis anther. Plant Cell 15: 2792-2804

YANG, W.-C., YE, D., XU, J. and SUNDARESAN, V. (1999). The SPOROCYTELESS gene of Arabidopsis is required for initiation of sporogenesis and encodes a novel nuclear protein. Genes Dev. 13: 2108-2117.

ZHANG, W., SUN, Y., TIMOFEJEVA, L., CHEN, C., GROSSNIKLAUS, U. and MA,
H. (2006). Regulation of Arabidopsis tapetum development and function by DYSFUNCTIONAL TAPETUM1 (DYT1) encoding a putative bHLH transcription factor. Development 133: 3085-3095.

ZHAO, D.-Z., WANG, G.-F., SPEAL, B. and MA, H. (2002). The EXCESS MICROSPOROCYTES1 gene encodes a putative leucine-rich repeat receptor protein kinase that controls somatic and reproductive cell fates in the Arabidopsis anther. Genes Dev. 16: 2021-2031.

\section{Further Related Reading, published previously in the Int. J. Dev. Biol.}

Multi-probe in situ hybridization to whole mount Arabidopsis seedlings

Leonardo Bruno, Antonella Muto, Natasha D. Spadafora, Domenico laria, Adriana Chiappetta, Mieke Van Lijsebettens and Maria B. Bitonti Int. J. Dev. Biol. (2011) 55: 197-203

Genetic analysis of reproductive development in tomato

Rafael Lozano, Estela Giménez, Beatriz Cara, Juan Capel and Trinidad Angosto

Int. J. Dev. Biol. (2009) 53: 1635-1648

\section{Chromatin remodeling in plant development}

José A. Jarillo, Manuel Piñeiro, Pilar Cubas and José M. Martínez-Zapater

Int. J. Dev. Biol. (2009) 53: 1581-1596

Plant Developmental Biology in Spain:

from the origins to our days and prospects for the future

José-Pío Beltrán

Int. J. Dev. Biol. (2009) 53: 1219-1234

Long-range signalling in plant reproductive development

Paula Suárez-López

Int. J. Dev. Biol. (2005) 49: 761-771

The making of gametes in higher plants

Leonor C. Boavida, Jörg D. Becker and José A. Feijó

Int. J. Dev. Biol. (2005) 49: 595-614

5 yr ISI Impact Factor $(2010)=2.961$
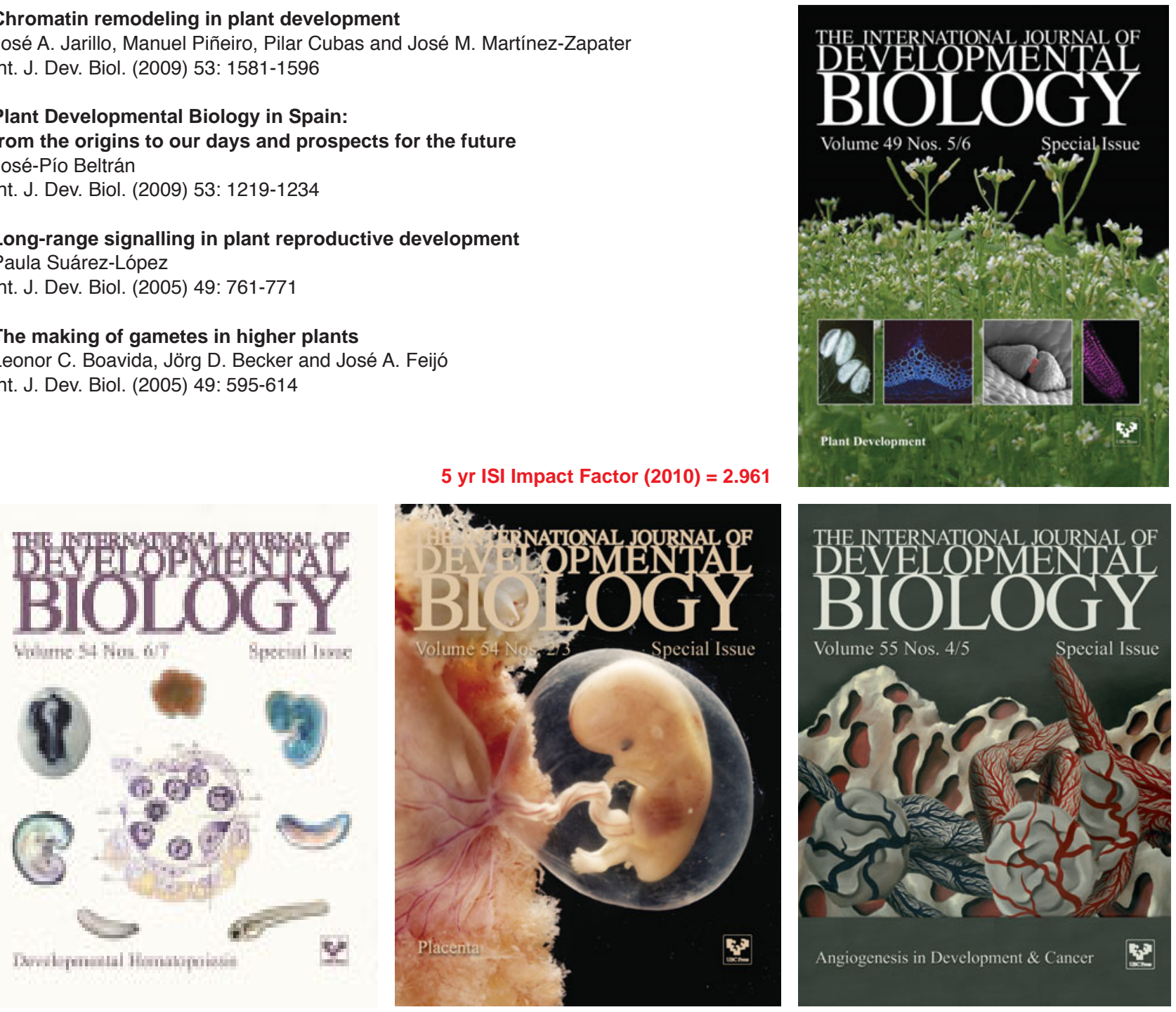